\title{
Targetable gene fusions identified in radioactive iodine refractory advanced thyroid carcinoma
}

\author{
K van der Tuin ${ }^{1}$, M Ventayol Garcia², W E Corver², M N Khalifa², D Ruano Neto², E P M Corssmit ${ }^{3}$, F J Hes ${ }^{1}$, \\ T P Links ${ }^{4}$, J W A Smit ${ }^{5}$, T S Plantinga ${ }^{6}$, E Kapiteijn', T van Wezel${ }^{2}$ and H Morreau $^{2}$
}

${ }^{1}$ Department of Clinical Genetics, ${ }^{2}$ Department of Pathology, ${ }^{3}$ Department of Medicine, Division of Endocrinology, Leiden University Medical Centre, Leiden, the Netherlands, ${ }^{4}$ Department of Endocrinology, University of Groningen, University Medical Center Groningen, Groningen, the Netherlands, ${ }^{5}$ Department of Medicine, Division of Endocrinology, , ${ }^{6}$ Department of Pathology, Radboud University Medical Center, Nijmegen, the Netherlands, and ${ }^{7}$ Department of Oncology, Leiden University Medical Centre, Leiden, the Netherlands

Correspondence should be addressed to $\mathrm{H}$ Morreau

Email

j.morreau@lumc.nl

\section{Abstract}

Objective: Gene alterations leading to activation of the MAPK pathway are of interest for targeted therapy in patients with advanced radioactive iodine refractory (RAI-R) thyroid carcinoma. Due to technical reasons gene fusion analysis in RNA isolated from formalin-fixed tumor tissues has till now been limited. The objective of the present study was to identify targetable gene rearrangements in RNA isolated from formalin-fixed RAI-R thyroid carcinomas.

Design: Retrospective study in 132 patients with RAI-R thyroid carcinoma (59 papillary-, 24 follicular-, 35 Hürthle cell- and 14 anaplastic thyroid carcinoma).

Methods: Total nucleic acid (undivided DNA and RNA) was isolated from formalin-fixed tissue. Extensive gene fusion analysis was performed in all samples that tested negative for pathogenic BRAF, NRAS, HRAS and KRAS variants. Results: Seven targetable gene fusions were identified in the remaining 60 samples without known DNA variants. This includes frequently reported gene fusions such as CCDC6/RET (PTC1), PRKAR1A/RET (PTC2) and ETV6/NTRK3, and gene fusions that are less common in thyroid cancer (TPM3/NTRK1, EML4/ALK and EML4/NTRK3). Of note, most gene fusions were detected in papillary thyroid carcinoma and MAPK-associated alterations in Hürthle cell carcinomas are rare $(2 / 35)$.

Conclusion: Targetable gene fusions were found in $12 \%$ of RAI-R thyroid carcinoma without DNA variants and can be effectively identified in formalin-fixed tissue. These gene fusions might provide a preclinical rationale to include specific kinase inhibitors in the treatment regimen for these patients. The latter intends to restore iodine transport and/or take advantage of the direct effect on tumor cell vitality once progressive disease is seen.

\section{Introduction}

Thyroid cancer (TC) is the most common endocrine malignancy with an increasing incidence over the past decades, accounting for $3.4 \%$ of all new malignant tumors (1). Differentiated thyroid cancer (DTC) is the most common subtype and includes papillary thyroid carcinoma (PTC, 80\%), follicular thyroid carcinoma (FTC, 10-15\%) and more rare subtypes like Hürthle cell carcinoma (HCC, $<5 \%)(2)$. Pathological subtypes of PTC include classical or conventional PTC (CPTC), follicular variant of PTC (FVPTC) and many rare subtypes. Anaplastic thyroid carcinoma (ATC) derives from follicular cells that have undergone dedifferentiation and represents less than (c) 2019 European Society of Endocrinology Printed in Great Britain
Published by Bioscientifica Ltd. 
$2 \%$ of all TCs. The current treatment for DTC includes total thyroidectomy and postoperative radioactive iodine (RAI) to ablate the remaining thyroid tissue and eliminate possible (micro) metastases (3). These treatments are highly effective in the majority of DTC patients and therefore the 10-year survival rate ranges between 80 and $95 \%$. However, nearly $5 \%$ of DTC patients become refractory to RAI (RAI-R) through a dedifferentiation process. The 10-year survival rate in these patients is less good $(20-40 \%)$ due to usually aggressive unresectable metastatic lesions $(4,5)$.

Point mutations (e.g. BRAF and RAS genes) as well as gene fusions (e.g. RET-PTC 1-12 and NTRK) leading to activation of the mitogen-activated protein kinase (MAPK) pathway are crucial for tumorigenesis and progression in thyroid tumors $(6,7,8,9,10)$. These mutations are almost always mutually exclusive (6). The fraction of protein kinase gene fusions is higher in thyroid carcinoma (8.5\%) compared to other tumor types (1-4.5\%) (11). Over the last decade, improved understanding of genetic pathways involved in thyroid tumorigenesis enabled the development of promising targeted therapies $(12,13)$.

The ability to detect gene fusions in RNA isolated from formalin-fixed, paraffin-embedded (FFPE) tumor tissues has been limited till now due to technical reasons. In this study, we succeeded in extensive gene fusion analysis on FFPE material intending to stratify RAI-R cases for targeted therapy.

\section{Subjects and methods}

\section{Sample selection, DNA/RNA extraction and mutation analysis}

FFPE tissue blocks were collected from 132 patients in the Netherlands with recurrent RAI-R thyroid carcinoma (primary tumor or lymph node metastasis). For the current study RAI-R was defined as either persistent or progressive disease on radiological images despite extensive RAI treatment or one or more measurable lesions that did not demonstrate RAI uptake on any RAI scan. All patient samples were handled in accordance with the Dutch medical ethical guidelines described in the Code for Proper Secondary Use of Human Tissue established by the Dutch Federation of Medical Sciences. That Code agrees with an augmented system of 'opt-out' for further use in scientific research of coded human tissue, unless there are special circumstances. The current study, including the used 'opt-out' policy, was approved by the Medical Ethical
Committee of the Leiden University Medical Centre, protocol no. B16.012. All patients were informed about the secondary use of tissue for research and none of the patients included in this study signed an objection form. In total 34 patients were previously included in phase II trials with Sorafenib (14) and/or Everolimus $(15,16)$ (Clinical-Trials.gov \#NCT00887107 and \#NCT01118065 respectively). For this manuscript, patient data were anonymized.

Total nucleic acid (undivided DNA and RNA) was isolated from FFPE tissue cores $(0.6 \mathrm{~mm}$ diameter and variable length) using a fully automated extraction procedure (17). DNA variant analysis (e.g. BRAF, NRAS, HRAS and KRAS) has been performed with either a customized AmpliSeq Cancer Hotspot Panel or with Sanger sequencing, depending on the time period as previously described $(18,19)$. Samples without DNA variants tested with Sanger sequencing were re-analyzed using the gene fusion data (see 'Data analysis' section below). Additional TERT promoter variant (NM_198253.2; c. $-57 \mathrm{~A}>\mathrm{C}$, c. $-124 \mathrm{C}>\mathrm{T}$ and c.-146 $\mathrm{C}>\mathrm{T}$ ) analysis was performed in 85 samples by Sanger sequencing. Tested cases did not significantly differ based on age of onset, gender, histological subtype and genetic alterations distribution from non-tested cases.

\section{Gene fusion analysis}

Gene fusion analysis was performed in all samples that tested negative for pathogenic BRAF, NRAS, HRAS and $K R A S$ variants. The whole procedure was executed using the FusionPlex comprehensive thyroid and lung kit v2 for Ion Torrent (ArcherDX Boulder, Colorado), according to the manufactures' protocol. If available, up to $200 \mathrm{ng}$ total nucleic acid were used for cDNA synthesis. The PreSeq RNA Quality Control (QC) assay was performed on $1 \mu \mathrm{L}$ cDNA using the VCP primer mix (ArcherDX) and iTaq Universal SYBR green supermix (Bio-Rad Laboratories). In this study, we proceeded with all samples irrespectively of the QC value. The cDNA fragments were prepared for the adaptor ligation with an end repair/dA-Tailing reaction. Moleculelevel barcoding (or unique molecule identifier tagging) and sample-level barcoding (also known as index tagging) are both incorporated during Archer MBC ligation. In the first and second PCR a specific primer set was used to cover relevant exons in 34 genes including ALK (exon 5'; 2, 4, 6, 10, 16-23, (intron19)), $A X L$ (exon 3'; 18-20), BRAF (exon $5^{\prime} ; 7-11$, exon $3^{\prime} ; 7,8,10$ ), CCND1 (exon 5'; 1-4, exon $3^{\prime} ; 1$ 1, 2, 4), FGFR1 (exon 5'; 2, 8-10, 17, exon 3'; 17), FGFR2 (exon 5'; 2, 5, 7-10, exon 3'; 17), FGFR3 (exon 5'; 3, 
5, 8-10, exon 3'; 17, (intron17)), MET (exon 5'; 2, 4-6, 13, $14,16,17,21$, exon $3^{\prime} ; 2$ ), NRG1 (exon $5^{\prime} ; 1-3,6$ ), NTRK1 (exon $\left.5^{\prime} ; 2,4,6,8,10-13\right)$, NTRK2 (exon 5'; 5, 7, 9, 11-17), NTRK3 (exon 5'; 4, 7, 10, 13-16), PPARG (exon 5'; 1-3, 5), RAF1 (exon 5'; 4-7, 9-12), RET (exon 5'; 2, 4, 6, 8, 9-14), ROS1 (exon 5'; 2, 4, 7, 31-37) and THADA (exon 3'; 24-30, $36,37)$. This method enables to detect known gene fusions as well as novel gene fusion partners. Final libraries were diluted 1:100 and quantified using Ion Library TaqMan Quantitation Kit (Thermo Fisher Scientific). The libraries were pooled (concentration $60 \mathrm{pM}$, loaded on a chip (Ion Chef System) and sequenced on an Ion Proton sequencer (Thermo Fisher Scientific).

\section{Data analysis}

Data analysis was performed using the online Archer Analysis software v5.0 (http://analysis.archerdx.com). Only 'strong-evidence' fusions within the software annotation were reported. Furthermore, BRAF/RAS point mutations were reported based on DNA/RNA reads. The total number of reads and the fractions of unique reads/ RNA reads were documented for all samples as possible quality indicators.

\section{Confirmation of fusion transcripts}

Identified gene fusions were validated using different methods. In the majority of cases, the presence of the fusion was confirmed with the FusionPlex on a second sample from the same patient (in most cases a lymph node metastasis). In one sample, the presence of the fusion was confirmed with Sanger sequencing, using the following primers: 5'-CATTCTTCCACCCTGGAAAC-3' (forward ETV6 exon 4), and 5'-GCTGAGTCCTCCTCACCACT-3' (reverse NTRK3 exon 13). Paraffin sections of the sample with EML4-ALK-fusions were immunostained for ALK fusion protein using standard procedures (Clone D5F3; 1:250 dilution, Cell Signaling Technology).

\section{Statistical analysis}

To describe the characteristics of the study population, the mean age at diagnosis with range was calculated. The median was estimated for the gene fusion test characteristics with a skewed distribution. Continuous variables were analyzed using an independent sample t-test or one-way ANOVA. Dichotomous variables were compared using the chi-squared test. The Kaplan-Meier method was used to estimate the survival function from lifetime data. Statistical significance was set at $P<0.05$ and the analyses were conducted using SPSS 23.0 (SPSS).

\section{Results}

We analyzed in total 132 RAI-R thyroid tumors including 52 PTC, 7 FVPTC, 24 FTC, 35 HCC and 14 ATC as illustrated in Fig. 1. The mean age ( \pm S.D.) at diagnosis of TC was $60 \pm 12$ years (range 16-84 years). In this study population, gender was evenly distributed, while it has previously been reported that the incidence of DTC

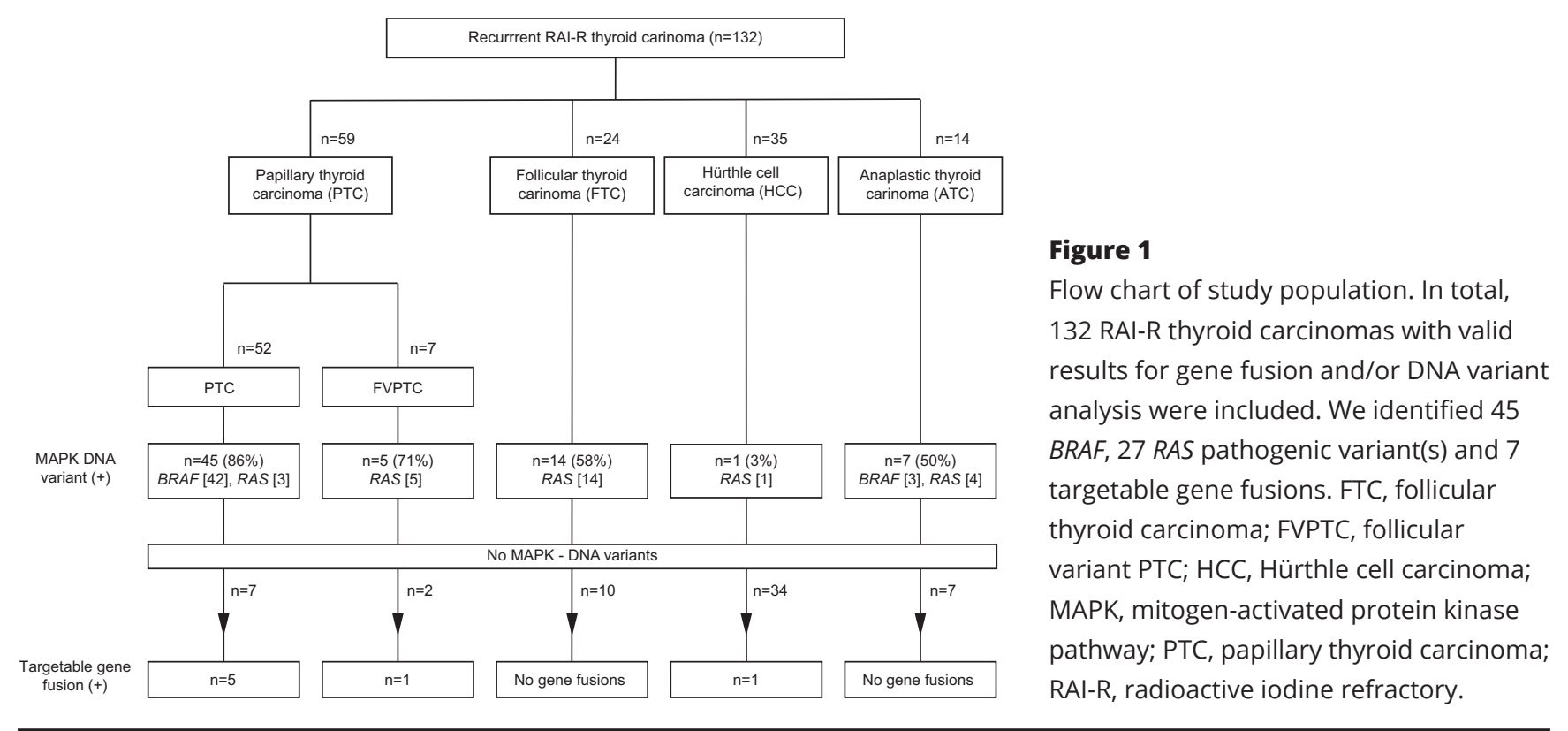


is significantly higher in women compared to men. Age of diagnosis and gender did not significantly differ between the histological subtypes or genetic alteration (Supplementary Table 1, see section on supplementary data given at the end of this article). The 5-year overall survival rates were 55\% in PTC, 43\% in FVPTC, 56\% in FTC, 31\% in HCC and 7\% ATC (Supplementary Fig. 1A).

The well-known driver variant $B R A F^{V 600 \mathrm{E}}$ was identified in 42 out of 52 PTCs ( $81 \%$ ) and in three ATCs. Pathogenic $\mathrm{N}-/ \mathrm{H}-/ K R A S$ variants were identified in PTC, FVPTC, FTC, HCC and ATC (6, 71, 58, 3 and 29\%, respectively). Pathogenic TERT promoter variants were found in 43 out of in total 87 tested samples, predominantly c. $-124 \mathrm{C}>\mathrm{T}(n=40)$ and less frequent c. $-146 \mathrm{C}>\mathrm{T}(n=3)$. Furthermore, one variant of uncertain significance was identified (c.-160 C>T). TERT variants were identified in all histological subtypes that is in PTC, FVPTC, FTC, HCC and ATC; $20 / 33=61,2 / 4=50,9 / 17=53,5 / 21=24$ and $7 / 12=58 \%$, respectively). TERT variants were present in samples with or without other genetic alterations (that is in combinations with $B R A F$ or $R A S$ variants, gene fusions and in cases with undetected genetic drivers; $18 / 28=64$, $8 / 16=50,3 / 5=60$ and $14 / 38=37 \%$ respectively).

Targetable gene fusions were identified in 7 out of 60 samples (12\%) without pathogenic BRAF/RAS variants. Clinicopathological and molecular characteristics of patients with targetable gene fusions are described in Table 1 . The following gene fusions were identified in classical PTC: CCDC6-RET (RET/PTC1), PRKAR1A-RET (RET/PTC2), ETV6-NTRK3 and EML4-ALK. Furthermore, a TPM3-NTRK1 gene fusion was identified in a variant PTC that we described as a 'sclerotic cribriform PTC without morulae'. One FVPTC harbored an EML4-NTRK1 gene fusion and another ETV6-NTRK3 gene fusion was identified in an HCC. Gene fusions were identified more frequently in PTC compared to FTC, HCC and ATC. All identified NTRK and ALK rearrangements maintained the entire kinase domain and lacked the transmembrane localization domain. Immunohistochemical staining showed ALK positive overexpression in the EML4-ALK sample (Supplementary Fig. 2).

The median number of total reads in all samples was 2123361 (range: 8435-5 648 828) and the median $\%$ of unique reads and RNA reads was 11.1\% (range: 5.9-69.5\%) and 33.7\% (range: 1.8-72.4\%), respectively. These parameters did not significantly differ among gene fusion-positive and fusion-negative cases.

Genetic alteration leading to activation of the MAPK pathway were eventually identified in $96 \%$ of PTC, $86 \%$ of FVPTC, $58 \%$ of FTC, $6 \%$ of HCC and $50 \%$ of ATC. In total, 53 tumors lacked gene alterations, including 10 FTC and 33 HCC. There was no statistical difference in overall survival between the different molecular backgrounds that is BRAF mutant, RAS mutant, gene fusion positive and DNA variant/gene fusion negative cases (Supplementary Fig. 1B).

Four patients now identified with a targetable gene fusion were already deceased, due to tumor progression despite Sorafenib, Everolimus or other treatments (age of death 62-75 years). The other three, recently diagnosed patients with recurrent disease did not report extensive disease-related complaints and were therefore not yet further treated with kinase inhibitors, according to the standard procedures in our center. However, these patients might benefit from therapeutic approaches with targeted inhibitors in case of tumor progression.

\section{Discussion}

We identified targetable RET, NTRK, BRAF or ALK gene fusions in 7 out of 60 (12\%) formalin-fixed thyroid carcinomas from patients with recurrent RAI-R disease without pathogenic BRAF/RAS variants. Remarkably, gene fusions were more common in PTC compared to other histological subtypes. The advent of extensive

Table 1 Clinicopathological and molecular characteristics of patients with targetable gene fusions.

\begin{tabular}{|c|c|c|}
\hline ID & Sex & Age at Dx (years) \\
\hline 1 & $\mathrm{~F}$ & 56 \\
\hline 2 & $\mathrm{~F}$ & 16 \\
\hline 3 & $\mathrm{M}$ & 73 \\
\hline 4 & $\mathrm{M}$ & 60 \\
\hline 5 & $\mathrm{M}$ & 65 \\
\hline 6 & $\mathrm{~F}$ & 60 \\
\hline 7 & $\mathrm{M}$ & 75 \\
\hline
\end{tabular}

\begin{tabular}{l} 
Histology \\
\hline Classical PTC \\
Classical PTC \\
Classical PTC \\
Classical PTC \\
FVPTC \\
Sclerotic cribriform PTC \\
$\quad$ without morulae \\
Hürthle cell carcinoma \\
\hline
\end{tabular}

\begin{tabular}{ccc}
\hline Gene fusion (exon no.) & & TERT variant \\
\cline { 1 - 1 } CCDC6 (e1)-RET (e12) & & C.-124 C $>\mathrm{T}$ \\
PRKAR1A (e8)-RET (e12) & Not tested \\
ETV6 (e4)-NTRK3 (e13) & Not tested \\
EML4 (e13)-ALK (e21) & C.-124 C>T \\
EML4 (e2)-NTRK3 (e14) & Wild type \\
TPM3 (e6)-NTRK1 (e11) & c.-124 C>T \\
ETV6 (e3)-NTRK3 (e13) & Wild type \\
\hline
\end{tabular}

\begin{tabular}{lcc}
\hline Status & & Follow-up (years) \\
\cline { 1 - 1 } DOD & 4 \\
AWD & 6 \\
DOD & 2 \\
AWD & 5 \\
AWD & 8 \\
DOD & 2 \\
DOD & 0 \\
\hline
\end{tabular}

AWD, alive with disease; DOD, death of disease; Dx, diagnosis thyroid carcinoma; F, female; FVPTC, follicular variant PTC; M, male; PTC, papillary thyroid carcinoma.

https://eje.bioscientifica.com 
gene fusion analysis on routinely processed FFPE tissues allowed stratification for targeted therapies for advanced thyroid cancer. This could be beneficial for patients whose tumors are either resistant to RAI immediately after surgery or show recurrent disease during follow-up. Our study showed that extensive gene fusion analysis on FFPE thyroid carcinoma samples is effective and feasible.

Although the genetic landscape of differentiated and less differentiated thyroid carcinoma has been extensively studied $(6,9,10)$, this is one of the largest series with recurrent RAI-R DTC in which molecular analysis has been performed. However, the number within different histological subtypes is still limited. For that reason, comparing the outcome of the different molecular backgrounds stratified by the histological subtype was not possible.

In samples with a low number of (unique) reads and/ or low fraction of RNA, the present gene fusions cannot be excluded with certainty. On the other hand, in one sample considered to be of low quality (only 5\% RNA reads) a validated TPM3-NTRK3 fusion has been found. Further evaluation of quality parameters in molecular diagnostics should lead to consensus criteria to prevent that low-quality samples are incorrectly reported to be negative for gene fusions.

Fifty-tree tumors lacked apparent driver mutations. Of note, as shown previously, HCCs were clearly overrepresented in this group $(n=35)$ and activating variants in MAPK genes are known to be rare in this subtype $(20,21)$. Recent studies showed that sequential loss of whole chromosomes is a dominant driver of the oncogenesis of HCC $(22,23,24)$. Furthermore, previous studies have shown that dysregulated miRNAs are related to cancer initiation and progression in several tumor types (25).

Understanding how genetic alterations contribute to the disease process is essential for the development of novel prognostic and therapeutic strategies. Identification of gene fusion transcripts leading to the activation of the transduction signaling pathways are of interest for targeted therapy, intending to restore iodine transport and/or take advantage of the direct effect on tumor cell vitality once progressive disease is seen. While progress has been made with the discovery of kinase inhibitors, the efficacy may be limited because of the development of resistance to treatment and severe side effects (26). Lenvatinib and Sorafenib are smallmolecule multi-targeted tyrosine kinase inhibitors (TKIs) and so far the only registered agents for the treatment of advanced DTC $(27,28)$. A number of selective inhibitors have been developed and characterized in preclinical and clinical studies in other tumor types. In November 2018, the American Food and Drug Administration approved Larotrectinib for patients with solid tumors that have a neurotrophic receptor tyrosine kinase (NTRK) gene fusion. NTRK gene fusions are present in 1-2\% of all PTCs (11), while our study showed even a larger contribution of these fusions in RAI-R PTC $(3 / 60=5 \%)$. Similar approaches could be feasible in DTCs with rearrangements involving $A L K, 0.6-2.2 \%$ of all PTC and $1 \%$ in our series $(29,30)$. Furthermore, LOXO-292 and BLU-667, selective and potent RET inhibitors $(31,32)$, are currently being studied in Phase1/2 trials. LOXO-292 demonstrates robust anti-tumor activity in RET fusion positive thyroid cancer, according to interim clinical data reported at the 2018 American Thyroid Association annual meeting. Recent preclinical and clinical studies with selumetinib, vemurafenib and dabrafenib showed re-differentiation, increased iodine uptake and retention in $B R A F$-mutated tumors $(33,34,35)$. Further studies are needed to investigate the most effective strategy; however, combination therapy appears to be a reasonable strategy to avoid resistance. Additional (targetable) alterations include variants in the phosphoinositide 3-kinase (PI3K) pathway (e.g. PIK3CA, PTEN, MTOR, TSC1 and TSC2). Everolimus, an inhibitor of the downstream mammalian target of rapamycin (mTOR) serine/threonine protein kinase, has shown to be a promising agent in recurrent RAI-R disease (15). Other PI3K/AKT/mTOR pathway inhibitors for the treatment of advanced solid cancers are currently tested in clinical trials (36). For current trails, see http://www.cancer.gov/about-cancer/treatment/ clinical-trials/search.

It has been suggested that ETV6-NTRK3 rearrangements are caused by radiation exposure, based on in vitro studies and case series of patients who suffered from the Chernobyl accident (37). NTRK3 fusions were also more frequently found in pediatric PTC, associated with more extensive disease and aggressive pathology (38). We identified three NTRK3 fusions in patients between 65 and 76 years old. To our knowledge, none of them had a history of extensive radiation exposure.

In conclusion, targetable gene fusions were found in $12 \%$ of recurrent RAI-R thyroid carcinoma without MAPKrelated DNA variants and can be effectively identified in routinely processed FFPE tissue. These gene fusions might provide a rationale to to treat these patients with specific kinase inhibitors, intending to restore iodine transport and/or take advantage of the direct effect on tumor cell vitality once progressive disease is seen. 


\section{Supplementary data}

This is linked to the online version of the paper at https://doi.org/10.1530/ EJE-18-0653.

\section{Declaration of interest}

The authors declare that there is no conflict of interest that could be perceived as prejudicing the impartiality of this study.

\section{Funding}

This study was supported in part by funding from of the 'Merel foundation' to $\mathrm{H} \mathrm{M}$ and a Archer Research Grant to $\mathrm{H} \mathrm{M}$ and T $v$ W. The funding bodies has not influenced the design of the study or collection, analysis and interpretation of data or writing the manuscript in any way.

\section{Author contribution statement}

$\mathrm{KT}$ reviewed the literature, collected the clinical and molecular information and wrote and edited the manuscript as major contributor. $\mathrm{M} \mathrm{V}$ and $\mathrm{M} \mathrm{N}$ contributed to sample preparation and performed the experiments, including validation. T P and W C contributed to sample preparation and helped to draft the manuscript. D R participated in the study design and implemented the bioinformatics. $\mathrm{F} \mathrm{H}$ participated in the study design and supervised and helped to draft the manuscript. E C, T L, J S and E K collected clinical information and helped to draft the manuscript. T W and $\mathrm{H} \mathrm{M}$ conceived the study, participated in its design and coordination, supervised and helped to draft the manuscript. H M carried out the pathological analysis of all thyroid carcinoma samples. All authors read and approved the final manuscript.

\section{Acknowledgements}

The authors acknowledge the laboratory for molecular diagnostics of the pathology department of the Leiden University Medical Centre, the Netherlands for their work with the genetic analysis. T van Wezel and $\mathrm{H}$ Morreau: contributed equally.

\section{References}

1 Siegel RL, Miller KD \& Jemal A. Cancer statistics, 2017. CA: A Cancer Journal for Clinicians 201767 7-30. (https://doi.org/10.3322/ caac.21387)

2 Lloyd RV, Buehler D \& Khanafshar E. Papillary thyroid carcinoma variants. Head and Neck Pathology 20115 51-56. (https://doi. org/10.1007/s12105-010-0236-9)

3 Haugen BR, Alexander EK, Bible KC, Doherty GM, Mandel SJ, Nikiforov YE, Pacini F, Randolph GW, Sawka AM, Schlumberger M et al. 2015 American Thyroid Association management guidelines for adult patients with thyroid nodules and differentiated thyroid cancer: the American Thyroid Association guidelines task force on thyroid nodules and differentiated thyroid cancer. Thyroid 201626 1-133. (https://doi.org/10.1089/thy.2015.0020)

4 Sherman SI. Thyroid carcinoma. Lancet 2003361 501-511. (https:// doi.org/10.1016/S0140-6736(03)12488-9)

5 Sciuto R, Romano L, Rea S, Marandino F, Sperduti I \& Maini CL. Natural history and clinical outcome of differentiated thyroid carcinoma: a retrospective analysis of 1503 patients treated at a single institution. Annals of Oncology 200920 1728-1735. (https:// doi.org/10.1093/annonc/mdp050)

6 Cancer Genome Atlas Research Network. Integrated genomic characterization of papillary thyroid carcinoma. Cell 2014159 676-690. (https://doi.org/10.1016/j.cell.2014.09.050)
7 Yoo SK, Lee S, Kim SJ, Jee HG, Kim BA, Cho H, Song YS, Cho SW, Won JK, Shin JY et al. Comprehensive analysis of the transcriptional and mutational landscape of follicular and papillary thyroid cancers. PLoS Genetics 201612 e1006239. (https://doi.org/10.1371/journal. pgen.1006239)

8 Pagan M, Kloos RT, Lin CF, Travers KJ, Matsuzaki H, Tom EY, Kim SY, Wong MG, Stewart AC, Huang J et al. The diagnostic application of RNA sequencing in patients with thyroid cancer: an analysis of 851 variants and 133 fusions in 524 genes. BMC Bioinformatics 201617 (Supplement 1) 6. (https://doi.org/10.1186/ s12859-015-0849-9)

9 Landa I, Ibrahimpasic T, Boucai L, Sinha R, Knauf JA, Shah RH, Dogan S, Ricarte-Filho JC, Krishnamoorthy GP, Xu B et al. Genomic and transcriptomic hallmarks of poorly differentiated and anaplastic thyroid cancers. Journal of Clinical Investigation 2016126 1052-1066. (https://doi.org/10.1172/JCI85271)

10 Pozdeyev N, Gay LM, Sokol ES, Hartmaier R, Deaver KE, Davis S, French JD, Borre PV, LaBarbera DV, Tan AC et al. Genetic analysis of 779 advanced differentiated and anaplastic thyroid cancers. Clinical Cancer Research 201824 3059-3068. (https://doi.org/10.1158/10780432.CCR-18-0373)

11 Yoshihara K, Wang Q, Torres-Garcia W, Zheng S, Vegesna R, Kim H \& Verhaak RG. The landscape and therapeutic relevance of cancerassociated transcript fusions. Oncogene 201534 4845-4854. (https:// doi.org/10.1038/onc.2014.406)

12 Worden F. Treatment strategies for radioactive iodine-refractory differentiated thyroid cancer. Therapeutic Advances in Medical Oncology 20146 267-279. (https://doi.org/10.1177/1758834014548188)

13 Petrulea MS, Plantinga TS, Smit JW, Georgescu CE \& Netea-Maier RT. PI3K/Akt/mTOR: a promising therapeutic target for non-medullary thyroid carcinoma. Cancer Treatment Reviews 201541 707-713. (https://doi.org/10.1016/j.ctrv.2015.06.005)

14 Schneider TC, Abdulrahman RM, Corssmit EP, Morreau H, Smit JW $\&$ Kapiteijn E. Long-term analysis of the efficacy and tolerability of sorafenib in advanced radio-iodine refractory differentiated thyroid carcinoma: final results of a phase II trial. European Journal of Endocrinology 2012167 643-650. (https://doi.org/10.1530/EJE12-0405)

15 Schneider TC, de Wit D, Links TP, van Erp NP, van der Hoeven JJ, Gelderblom H, Roozen IC, Bos M, Corver WE, van Wezel T et al. Everolimus in patients with advanced follicular-derived thyroid cancer: results of a phase II clinical trial. Journal of Clinical Endocrinology and Metabolism 2017102 698-707. (https://doi. org/10.1210/jc.2016-2525)

16 Schneider TC, de Wit D, Links TP, van Erp NP, van der Hoeven JJ, Gelderblom H, van Wezel T, van Eijk R, Morreau H, Guchelaar HJ et al. Beneficial effects of the mTOR inhibitor everolimus in patients with advanced medullary thyroid carcinoma: subgroup results of a phase II trial. International Journal of Endocrinology 20152015348124. (https://doi.org/10.1155/2015/348124)

17 van Eijk R, Stevens L, Morreau H \& van Wezel T. Assessment of a fully automated high-throughput DNA extraction method from formalin-fixed, paraffin-embedded tissue for KRAS, and BRAF somatic mutation analysis. Experimental and Molecular Pathology 201394 121-125. (https://doi.org/10.1016/j.yexmp.2012.06.004)

18 Corver WE, Ruano D, Weijers K, den Hartog WC, van Nieuwenhuizen MP, de Miranda N, van Eijk R, Middeldorp A, Jordanova ES, Oosting J et al. Genome haploidisation with chromosome 7 retention in oncocytic follicular thyroid carcinoma. PLoS ONE 20127 e38287. (https://doi.org/10.1371/journal. pone.0038287)

19 Sibinga Mulder BG, Mieog JS, Handgraaf HJ, Farina Sarasqueta A, Vasen HF, Potjer TP, Swijnenburg RJ, Luelmo SA, Feshtali S, Inderson A et al. Targeted next-generation sequencing of FNA-derived DNA in pancreatic cancer. Journal of Clinical Pathology $2017 \mathbf{7 0}$ 174-178. (https://doi.org/10.1136/jclinpath-2016-203928) 
20 Evangelisti C, de Biase D, Kurelac I, Ceccarelli C, Prokisch H, Meitinger T, Caria P, Vanni R, Romeo G, Tallini G et al. A mutation screening of oncogenes, tumor suppressor gene TP53 and nuclear encoded mitochondrial complex I genes in oncocytic thyroid tumors. BMC Cancer 201515 157. (https://doi.org/10.1186/s12885015-1122-3)

21 Ganly I, Ricarte Filho J, Eng S, Ghossein R, Morris LG, Liang Y, Socci N, Kannan K, Mo Q, Fagin JA et al. Genomic dissection of Hurthle cell carcinoma reveals a unique class of thyroid malignancy. Journal of Clinical Endocrinology and Metabolism 201398 E962-E972. (https://doi.org/10.1210/jc.2012-3539)

22 Gopal RK, Kubler K, Calvo SE, Polak P, Livitz D, Rosebrock D, Sadow PM, Campbell B, Donovan SE, Amin S et al. Widespread chromosomal losses and mitochondrial DNA alterations as genetic drivers in Hurthle cell carcinoma. Cancer Cell 201834 242.e5-255.e5. (https://doi.org/10.1016/j.ccell.2018.06.013)

23 Corver WE, van Wezel T, Molenaar K, Schrumpf M, van den Akker B, van Eijk R, Ruano Neto D, Oosting J \& Morreau H. Nearhaploidization significantly associates with oncocytic adrenocortical, thyroid, and parathyroid tumors but not with mitochondrial DNA mutations. Genes, Chromosomes and Cancer 201453 833-844. (https://doi.org/10.1002/gcc.22194)

24 Ganly I, Makarov V, Deraje S, Dong Y, Reznik E, Seshan V, Nanjangud G, Eng S, Bose P, Kuo F et al. Integrated genomic analysis of Hurthle cell cancer reveals oncogenic drivers, recurrent mitochondrial mutations, and unique chromosomal landscapes. Cancer Cell 201834 256-270.e5. (https://doi.org/10.1016/j. ccell.2018.07.002)

25 Croce CM. Causes and consequences of microRNA dysregulation in cancer. Nature Reviews Genetics 200910 704-714. (https://doi. org/10.1038/nrg2634)

26 Choi SH, Kim DH, Choi YJ, Kim SY, Lee JE, Sung KJ, Kim WS, Choi CM, Rho JK \& Lee JC. Multiple receptor tyrosine kinase activation related to ALK inhibitor resistance in lung cancer cells with ALK rearrangement. Oncotarget 20178 58771-58780. (https:// doi.org/10.18632/oncotarget.17680)

27 Brose MS, Nutting CM, Jarzab B, Elisei R, Siena S, Bastholt L, de la Fouchardiere C, Pacini F, Paschke R, Shong YK et al. Sorafenib in radioactive iodine-refractory, locally advanced or metastatic differentiated thyroid cancer: a randomised, double-blind, phase 3 trial. Lancet 2014384 319-328. (https://doi.org/10.1016/S01406736(14)60421-9)

28 Schlumberger M, Tahara M, Wirth LJ, Robinson B, Brose MS, Elisei R, Habra MA, Newbold K, Shah MH, Hoff AO et al. Lenvatinib versus placebo in radioiodine-refractory thyroid cancer. New England Journal of Medicine 2015372 621-630. (https://doi.org/10.1056/ NEJMoa1406470)
29 Chou A, Fraser S, Toon CW, Clarkson A, Sioson L, Farzin M, Cussigh C, Aniss A, O'Neill C, Watson $\mathrm{N}$ et al. A detailed clinicopathologic study of ALK-translocated papillary thyroid carcinoma. American Journal of Surgical Pathology 201539 652-659. (https://doi.org/10.1097/PAS.0000000000000368)

30 Kelly LM, Barila G, Liu P, Evdokimova VN, Trivedi S, Panebianco F, Gandhi M, Carty SE, Hodak SP, Luo J et al. Identification of the transforming STRN-ALK fusion as a potential therapeutic target in the aggressive forms of thyroid cancer. PNAS 2014111 4233-4238. (https://doi.org/10.1073/pnas.1321937111)

31 Subbiah V, Gainor JF, Rahal R, Brubaker JD, Kim JL, Maynard M, $\mathrm{Hu}$ W, Cao Q, Sheets MP, Wilson D et al. Precision targeted therapy with BLU-667 for RET-driven cancers. Cancer Discovery $2018 \mathbf{8}$ 836-849. (https://doi.org/10.1158/2159-8290.CD-18-0338)

32 Subbiah V, Velcheti V, Tuch BB, Ebata K, Busaidy NL, Cabanillas ME, Wirth LJ, Stock S, Smith S, Lauriault V et al. Selective RET kinase inhibition for patients with RET-altered cancers. Annals of Oncology 201829 1869-1876. (https://doi.org/10.1093/annonc/mdy137)

33 Cheng L, Jin Y, Liu M, Ruan M \& Chen L. HER inhibitor promotes BRAF/MEK inhibitor-induced redifferentiation in papillary thyroid cancer harboring BRAFV600E. Oncotarget 20178 19843-19854. (https://doi.org/10.18632/oncotarget.15773)

34 Ho AL, Grewal RK, Leboeuf R, Sherman EJ, Pfister DG, Deandreis D, Pentlow KS, Zanzonico PB, Haque S, Gavane S et al. Selumetinibenhanced radioiodine uptake in advanced thyroid cancer. New England Journal of Medicine 2013368 623-632. (https://doi. org/10.1056/NEJMoa1209288)

35 Rothenberg SM, McFadden DG, Palmer EL, Daniels GH \& Wirth LJ. Redifferentiation of iodine-refractory BRAF V600E-mutant metastatic papillary thyroid cancer with dabrafenib. Clinical Cancer Research 201521 1028-1035. (https://doi.org/10.1158/1078-0432.CCR-142915)

36 Li X, Dai D, Chen B, Tang H, Xie X \& Wei W. Efficacy of PI3K/ AKT/mTOR pathway inhibitors for the treatment of advanced solid cancers: a literature-based meta-analysis of 46 randomised control trials. PLOS ONE 201813 e0192464. (https://doi.org/10.1371/journal. pone.0192464)

37 Leeman-Neill RJ, Kelly LM, Liu P, Brenner AV, Little MP, Bogdanova TI, Evdokimova VN, Hatch M, Zurnadzy LY, Nikiforova MN et al. ETV6-NTRK3 is a common chromosomal rearrangement in radiation-associated thyroid cancer. Cancer 2014 120 799-807. (https://doi.org/10.1002/cncr.28484)

38 Prasad ML, Vyas M, Horne MJ, Virk RK, Morotti R, Liu Z, Tallini G, Nikiforova MN, Christison-Lagay ER, Udelsman R et al. NTRK fusion oncogenes in pediatric papillary thyroid carcinoma in northeast United States. Cancer 2016122 1097-1107. (https://doi.org/10.1002/ cncr.29887)

Received 30 August 2018

Revised version received 28 December 2018

Accepted 21 January 2019 